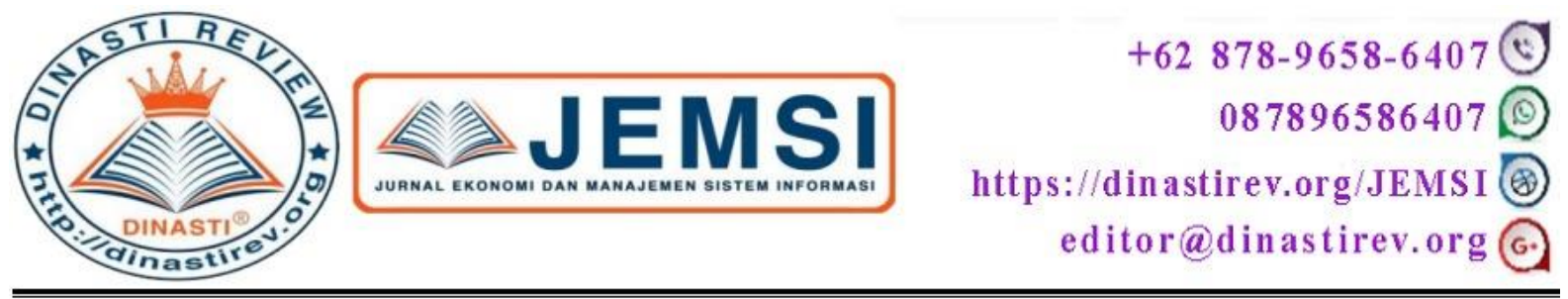

\title{
KODE ETIK \& PEDOMAN PERILAKU DALAM ETIKA BISNIS DI PT AJ ADISARANA WANAARTHA
}

\section{Kiki Lumban Gaol}

Universitas Mercu Buana, Jakarta, Indonesia

ARTICLE INFORMATION

Received: 17 April 2020

Revised: 22 April 2020

Issued: 1 Mei 2020

Corresponding author:

Kiki Lumban Gaol

E-mail: kikilumbangaol@yahoo.com

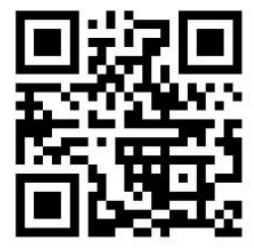

DOI:10.31933/JEMSI
Abstrak: Setiap Perusahaan atau Pelaku Bisnis dalam aktivitas bisnis yang dilakukan tidak bisa terlepas dari kualitas moralnya dalam menjalankan suatu Bisnis tersebut. Penerapan Etika Bisnis merupakan syarat utama Perusahaan agar mampu menjaga nama baik Perusahaan, mampu bersaing dan meminimalisir setiap resiko yang mungkin dihadapi oleh Perusahaan. Maraknya pelanggaran Etika Bisnis dalam berbagai industri khususnya industri Asuransi yang ada di Indonesia melatarbelakangi penulis melakukan penelitian terhadap penerapan Etika Bisnis pada perusahaan PT AJ Adisarana Wanaartha. Penelitian ini menunjukkan bahwa seluruh Karyawan, Manajer, Agen, dan Direksi PT AJ Adisarana Wanaartha sudah menerapkan kode etik dan pedoman perilaku yang dimiliki Perusahaan dalam menjalankan kegiatan operasional sehari-hari.

Kata Kunci: Etika Bisnis, Kode Etik, Pedoman Perilaku

\section{PENDAHULUAN}

Pelaku Bisnis dalam setiap aktivitasnya tidak bisa terlepas dari kualitas moralnya dalam menjalankan suatu Bisnis tertentu. Pelaku Bisnis dalam hal ini dapat kita anggap sebagai Perusahaan-perusahaan penggerak ekonomi Negara, semakin konsisten suatu Perusahaan menjalankan bisnis dengan nilai moral yang tinggi dan berperilaku etis maka Perusahaan tersebut akan semakin baik dampaknya bagi pertumbuhan perekonomian suatu Negara. Untuk itu, setiap Perusahaan atau pelaku bisnis perlu memiliki pedoman perilaku dan nilai-nilai etika untuk dijadikan tolak ukur dalam berbisnis serta untuk mendukung berjalannya kegiatan operasional yang memiliki dampak baik bukan hanya kepada Karyawan dan Para stakeholder, dan Mitra Perusahaan melainkan untuk kepentingan perekonomian suatu Negara juga. 
Adapun kaitan Etika dalam bidang Ekonomi dan Bisnis sudah akrab dengan nama "Etika Bisnis", sejalan dengan kebiasaan umum dalam istilah Bahasa Inggris yaitu "Business Ethics". Weiss (1994) menyatakan bahwa etika yang baik berarti bisnis yang baik. Hal ini sangat sesuai dengan pengamatan terhadap perusahaan yang sudah sukses bahwa Etikalah yang diutamakan, selain pemerolehan laba. Karena itu, V.F. Henderson menyatakan "Kita ingin menyadarkan dan menanamkan kesopansantunan dan kebaikan hati dalam sanubari pelaku bisnis tanpa harus menggoyahkan semangatnya (Henderson, 1992).

Perhatian terhadap Etika Bisnis semakin meningkat di kalangan dunia bisnis, hal ini dapat dilihat dari Perusahaan-perusahaan besar multinasional telah mempunyai kode etik. Namun, belakangan ini semakin banyak perusahaan yang menjalankan bisnis yang tidak sesuai dengan berbagai aturan dan ketentuan-ketentuan yang berlaku, Perusahaan cenderung melanggar kode etik yang sudah dibuat sendiri oleh Perusahaan tersebut hanya demi mengedepankan kepentingan personal maupun kelompok Perusahaan tertentu. Kode Etik dan pedoman perilaku yang ada hanya dijadikan sebagai formalitas dan identitas nilai-nilai Perusahaan saja, namun tidak pernah di terapkan oleh Karyawan dan seluruh Jajaran Direksi beserta para Stakeholder, khususnya bisnis asuransi sehingga mengurangi rasa percaya masyarakat terhadap perusahaan-perusahaan Asuransi yang ada di Indonesia. Dampak dari pelanggaran Etika Bisnis sangat besar bagi perusahaan-perusahaan yang menjalankan bisnis yang sama dan juga keadaan Ekonomi Negara. Maraknya pelanggaran Etika Bisnis dalam berbagai industri khususnya industri Asuransi yang ada di Indonesia melatarbelakangi penulis melakukan penelitian terhadap penerapan Etika Bisnis pada perusahaan PT AJ Adisarana Wanaartha.

PT AJ Adisarana Wanaartha telah melayani masyarakat Indonesia selama lebih dari 44 tahun sejak didirikan pada tahun 1974. PT AJ Adisarana Wanaartha hingga sampai saat ini selalu terus mengembangkan produk yang ditawarkan baaik Produk individu maupun grup untuk semua kebutuhan perencanaan keuangan masyarakat. Selain itu, PT AJ Adisarana Wanaartha percaya bahwa kemudahan aksesibilitas merupakan faktor yang sangat penting, untuk itu Perusahaan membuat strategi perluasan Marketing Distribution Channels dengan tiga jalur distribusi, yaitu Agency, Bancassurance dan Grup.

Sebagai perusahaan asuransi yang mempunyai visi untuk menjadi Perusahaan Asuransi yang multinasional terkemuka, dengan kepercayaan sebagai salah satu nilai Perusahaan, maka PT AJ Adisarana Wanaartha memiliki komitmen untuk menunjukkan perilaku yang beretika, memiliki integritas dan kepatuhan pada peraturan. PT AJ Adisarana Wanaartha memiliki kode etik dan pedoman perilaku yang merupakan pedoman dan dan panduan tertinggi untuk mendorong standar integritas, kepatuhan pada peraturan, dan etika perilaku di Perusahaan.

Etika Bisnis pada PT AJ Adisarana Wanaartha berlaku sebagai etika dan integritas bisnis perusahaan, yang bukan hanya sekedar pemenuhan Peraturan dan Undang-Undang. Dalam praktek kesehariannya kode etik dan pedoman perilaku ini berlaku bagi seluruh Karyawan tanpa terkecuali. Dengan adanya kode etik dan pedoman perilaku ini, setiap Karyawan diharapkan memiliki kesadaran resiko yang mungkin timbul jika melanggar kode etik dan pedoman perilaku yang berlaku di Perusahaan.

\section{KAJIAN PUSTAKA}

\section{Etika menurut para ahli}


Konsep etika berasal dari bahasa Yunani, yang dalam bentuk tunggal adalah ethos dan dalam bentuk jamak adalah ta etha (Bertens, 1997:4). Menurut Bertens (1997:224), ethos menunjukkan ciri-ciri, pandangan dan nilai yang menandai kelompok tertentu atau yang menurut Consice Oxford Dictionary : "characteristic spirit of community, people or system". Hal ini tercermin pada konsep etos kerja atau etos profesi. Semangat, ciri-ciri, dan pandangan khas yang dirumuskan untuk profesi tertentu disebut kode etik, misalnya kode etik kedokteran, kode etik perusahaan, kode etik guru, dan sebagainya.

Menurut Subagio et al (2013) Etika dipandang sebagai cabang ilmu dari ilmu filsafat sehubungan dengan nilai dari perilaku manusia dengan memandang pada tindakan yang benar dan salah serta benar dan buruknya motif dan tujuannya. Dari beberapa studi yang dilakukan, ada beberapa pendekatan penting mengenai etika, yaitu :

1. Prinsip Imperatif

Kewajiban tidak terkondisi di mana semua orang sadara akan adanya peaturan dan setuju untuk mengikuti peraturan tersebut.

2. Prinsip Utulitarian

Mneyarankan bahwa masalah etika harus diselesaikan dengan mengukur dari sisi konsekuensi baik dan konsekuensi buruknya.

3. Prinsip Generalisasi

Jika semua orang bertindak dalam lingkungan yang sama dan bertindak dengan cara tertentu sementara akibatnya tidak sesuai dengan yang diharapkan maka tidak ada kewajiban untuk bertindak dengan cara tersebut.

Yosephus (2010), mengemukakan tujuan atau sasaran dari etika adalah sebagai berikut :

1. Etika membantu kita untuk mampu mengambil sikap yang tepat pada saat menghadapi konflik nilai.

Dalam keseharian hidup tentu kita selalu atau paling kurangg pernah berhadapan dengan banyak orang dari berbagai kalanggan dengan beraneka pandangan tentang nilai-nilai dan norma untuk berperilaku sebagai orang baik dan benar. Dalam kemajemukannya itulah setiap komunitas masyarakat tentu menjunjung tinggi norma dan nilai komunitasnya sendiri. Paling tidak pertimbangan etis akan memberikan pemahaman yang lebih mendasar, lebih sistematis dan kritis perihal ajaran atau pandangan moral manakah yang semestinya diterapkan secara bertanggung jawab ketika berada di komunitas yang lain.

2. Etika membantu kita untuk mengambil sikap yang tepat dalam menghadapi transformasi di segala bidang kehidupan sebagai akibat modernisasi

Etika merupakan sarana yang memampukan kita untuk menentukan manakah nilainilai budaya yang relevan dengan tuntutan zaman, karenanya harus dipertahankan dan dikembangkan dan manakah nilai-nilai budaya yang memang harus ditinggalkan karena berseberangan atau tidak searah dengan perkembangan zaman.

3. Etika memampukan kita untuk selalu bersikap kritis terhadap berbagai ideologi baru. Etika membuat kita untuk tidak terlalu mudah tergoda oleh daya tarik ideologyideologi baru, namun juga tidak serta merta menolak nilai-nilai baru yang ditawarkan dalam ideologi-ideologi yang baru itu hanya karena alasan masih baru dan belum terbiasa. 


\section{Etika Bisnis (Business Ethic)}

Etika Bisnis (Business Ethics) yang diterapkan oleh suatu perusahaan biasanya berasal dari motif laba, motif hukum, dan kewajiban moral umum. Tujuan etika bisnis yang umum diterapkan dalam organisasi atau perusahaan adalah untuk menghindari pelanggaran hukum pidana dalam pekerjaan, menghindari tindakan yang dapat mengakibatkan gugatan hukum perdata pada perusahaan dan menghindari tindakan yang berakibat buruk bagi citra perusahaan, bisnis sangat berkaitan dengan tiga hal tersebut karena dapat mengakibatkan hilangnya uang dan reputasi perusahaan (Subagio et al, 2013).

Perilaku etis yang layak terletak di atas hukum. Hukum hanya menspesifikasi standar ukuran perilaku umum yang paling rendah, yang bisa diterima (Gene Laczniack, 1983).

Ada beberapa etika dalam berbisnis yang wajib diketahui oleh para pelaku bisnis, agar usaha yang sedang dijalankan dapat tetap berjalan dengan baik dan lancar, yaitu :

1. Jujur dalam berkomunikasi dan bersikap

2. Memiliki komitmen dan memenuhi janji

3. Memiliki Integritas

4. Memiliki loyalitas

Dengan demikian etika bisnis merupakan cara untuk melakukan kegiatan bisnis, yang mencakup seluruh aspek yang berkaitan dengan individu, perusahaan dan juga masyarakat. Etika bisnis dalam suatu perusahaan dapat membentuk nilai, norma dan perilaku karyawan serta pimpinan dalam membangun hubungan yang adil dan sehat dengan pelanggan/mitra kerja, pemegang saham, masyarakat. perusahaan menyakini prinsip bisnis yang baik adalah bisnis yang beretika, yakni bisnis dengan kinerja unggul dan berkesinambungan yang dijalankan dengan menaati kaidah-kaidah etika sejalan dengan hukum dan peraturan yang berlaku.

\section{Manfaat dan Tujuan Etika Bisnis Bagi Perusahaan}

Menurut Echdar,S. Maryadi (2019), manfaat etika bisnis bagi perusahaan adalah sebagai berikut :

1. Dapat meningkatkan kredibilitas suatu perusahaan, karena etika telah dijadikan sebagai corporate culture.

2. Dapat membantu menghilangkan Grey Area (kawasan kelabu) dibidang etika (penerimaan komisi, penggunaan tenaga kerja anak, kewajiban perusahaan dalam melindungi lingkungan hidup).

3. Menjelaskan bagaimana perusahaan menilai tanggung jawab sosialnya.

4. Menyediakan bagi perusahaan dan dunia bisnis pada umumnya, kemungkinan untuk mengatur diri sendiri (self regulation).

5. Bagi perusahaan yang telah go public dapat memperoleh manfaat berupa meningkatnya kepercayaan para investor. Selain itu karena adanya kenaikan harga saham, maka dapat menarik minat para investor untuk membeli saham perusahaan tersebut.

6. Dapat meningkatkan daya saing (competitive advantage) perusahaan.

7. Membangun corporate image/citra positif, serta dalam jangka panjang dapat menjaga kelangsungan hidup perusahaan (sustainable company) 
Menurut Subagio et al (2013) Tujuan Etika Bisnis yang umum diterapkan dalam organisasi adalah sebagai berikut :

1. Menghindari pelanggaran hukum pidana dalam pekerjaan.

2. Menghindari tindakan yang dapat mengakibatkan gugatan hukum perdata terhadap Perusahaan.

3. Menghindari tindakan yang berakibat buruk bagi citra Perusahaan.

Bisnis sangat berkaitan dengan tiga hal di atas karena dapat mengakibatkan hilangnya uang dan reputasi perusahaan.

\section{Pentingnya Etika dalam dunia Bisnis}

Menurut Echdar, S. Maryadi (2019), pentingnya etika bisnis berlaku dalam dua perspektif yaitu sebagai berikut :

1. Perspektif Makro

Pertumbuhan suatu Negara tergantung pada market system yang berperan lebih efektif dan efisien daripada command system dalam mengalokasikan barang dan jasa. Beberapa kondisi yang diperlukan market system untuk dapat efektif, yaitu :

a. Hak memiliki dan mengelola property swasta

b. Kebebasan memilih dalam perdagangan barang dan jasa

c. Ketersediaan informasi yang akurat berkaitan dengan barang dan jasa.

Jika salah satu sub system dalam market system melakukan perilaku yang tidak etis, maka hal ini akan mempengaruhi keseimbangan sistem dan menghambat pertumbuhan sistem secara makro.

2. Perspektif Mikro

Dalam lingkup ini perilaku etik identik dengan kepercayaan atau trust. Dalam lingkup mikro terdapat rantai relasi dimana supplier, perusahaan, konsumen, karyawan saling berhubungan kegiataan bisnis yang akan berpengaruh pada lingkup makro. Tiap mata rantai penting dampaknya untuk selalu menjaga etika, sehingga kepercayaan yang mendasari hubungan bisnis dapat terjaga dengan baik.

Beberapa hal yang mendasari pentingnya etika dalam kegiatan bisnis, yaitu :

1. Selain mempertaruhkan barang dan uang untuk tujuan keuntungan, bisnis juga mempertaruhkan nama, harga diri, bahkan nasib manusia yang terlibat di dalamnya.

2. Bisnis adalah bagian penting dalam masyarakat

3. Bisnis juga membutuhkan etika yang setidaknya mampu memberikan pedoman bagi para pihak dan stakeholders yang melakukannya.

Menurut Subagio et al (2013) ada tiga jenis motif dalam menjalankan etika dalam bisnis, yaitu :

1. Motif Laba

Ketika Perusahaan melakukan kebaikan (etika) maka salah satu motivasi Perusahaan tersebut adalah untuk mendapatkan laba yang lebih baik.

2. Motif Hukum

Perusahaan menjalankan bisnis dengan etika karerna takut ditindak secara hukum

3. Motif Moral 
Perusahaan melakukan operasi bisnis secara etika karena ingin melakukan kebaikan.

\section{METODE PENELITIAN}

Pada penelitian ini penulis akan membahas tentang penerapan Business Ethic pada PT AJ Adisarana Wanaartha. Metode penelitian yang digunakan adalah metode penelitian deskriptif dengan pendekatan analisis data sekunder (ADS). Penelitian deskriptif yang dilakukan bertujuan untuk mendeskripsikan, mencatat, menganalisis dan menginterpretasikan kondisi-kondisi yang saat ini berlangsung Perusahaan yang diteliti. Informasi-informasi yang digunakan pada penelitian ini diperoleh penulis dengan menggunakan data sekunder yang dapat diakses melalui berbagai media seperti website perusahaan, jurnal-jurnal, literature, buku peraturan perusahaan, kode etik dan pedoman perilaku yang berlaku di Perusahaan, serta buku-buku yang memiliki teori yang relevan dengan topik penelitian.

Dalam penelitian ini penulis tidak bermaksud untuk menjelaskan suatu hubungan antarvariabel, penulis menggambarkan suatu penerapan etika bisnis yang saat ini diterapkan oleh perusahaan, dan indikator-indikator tertentu yang menjadi pedoman bagi seluruh seluruh Karyawan, Manajer, Direktur dalam bekerja serta beraktifitas di lingkungan Perusahaan.

\section{HASIL DAN PEMBAHASAN}

Dalam menjalankan aktivitas operasional sehari-hari Perusahaan, seluruh karyawan beserta pihak manajemen diwajibkan menerapkan etika bisnis sebagai pedoman dalam berperilaku. Kode Etik dan pedoman perilaku yang berlaku di Perusahaan merupakan suatu landasan dan petunjuk nyata untuk berperilaku sesuai dengan nilai, komitment Perusahaan, serta Visi dan Misi Perusahaan.

PT AJ Adisarana Wanaartha memiliki komitmen yang besar untuk menerapkan keahlian dalam memberikan layanan perencanaan keuangan bagi individu maupun Grup dan terus meningkatkan pelayanan kepada pelanggan. Pelayanan terbaik menjadi elemen penting untuk menjunjung tinggi cerminan nilai-nilai pokok yang disingkat dengan "SATU" yang berarti :

\section{Service Excellence}

Dengan semakin ketatnya persaingan di industri Asuransi Jiwa, dimana produk yang dijual relatif sama, maka yang membedakan antara satu perusahaan dengan lainnnya adalah service yang menjadi culture bagi setiap perusahaan asuransi.

2. Advance

PT AJ Adisarana Wanaartha mempersiapkan teknologi dan sistem operasional yang terdepan dan mempersiapkan pribadi yang unggul (Advance) untuk memberikan pelayanan yang jauh lebih baik lagi kepada seluruh nasabah.

3. Trust

PT AJ Adisarana Wanaartha terbukti selama 44 tahun selalu menepati janji kepada seluruh nasabah, hal ini sebagai bentuk komitmen Perusahaan untuk menjaga kepercayaan (Trust) yang akan Perusahaan pertahankan secara terus menerus.

4. Unity 
Mempunyai visi yang sama dan selalu satu kesatuan (Unity) antara stakeholder, tenaga pemasaran, dan seluruh karyawan dalam melayani nasabah lebih baik lagi merupakan komitmen Perusahaan, sehingga Perusahaan menjadi sahabat bagi masyarakat Indonesia.

Etika Bisnis yang diterapkan pada PT AJ Adisarana Wanaartha merupakan pedoman dan panduan tertinggi untuk mendorong standar integritas, kepatuhan pada peraturan, dan etika berperilaku di Perusahaan, sebagai perlindungan atas aset, reputasi dan nama baik Perusahaan. Ketika dalam bekerja seorang karyawan menghadapi situasi-situasi yang memerlukan pedoman tertentu namun tidak dibuat khusus oleh Perusahaan, Karyawan tersebut dapat menggunakan kode etik dan pedoman yang berlaku di Perusahaan sebagai panduan untuk membantu, selain dari akal sehat, penilaian bijak, dan kesadaran resiko yang mungkin timbul.

Etika Bisnis yang dibuat berlaku bagi Karyawan, Manajemen dan Direktur Perusahaan, serta Mitra Bisnis tertentu seperti Agen yang memiliki lisensi AAJI (Asosiasi Asuransi Jiwa Indonesia) atas nama PT AJ Adisarana Wanaartha, diharapkan untuk menaati kode etik dan pedoman perilaku serta semua ketentuan kontrak yang berlaku di Perusahaan. Penyusunan Etika Bisnis PT AJ Adisarana Wanaartha bertujuan sebagai standar etika dan integritas dalam berbisinis, yang bukan hanya sekedar pemenuhan Peraturan dan UndangUndang. Dalam hal ketentuan pada Etika Bisnis yang berlaku berbeda dengan Peraturan Perundang-Undangan yang berlaku di Indonesia, maka ketentuan yang dianggap berlaku adalah ketentuan yang paling ketat, kecuali hal tersebut bertentangan dengan UndangUndang.

Pedoman Perilaku bagi seluruh Karyawan PT AJ Adisarana Wanaartha adalah sebagai berikut :

1. Mematuhi kode dan pedoman serta Peraturan Perundang-undangan yang berlaku.

2. Secara aktif mencari nasihat atas pertanyaan yang berkaitan dengan Kode Etik dan Pedoman perilaku.

3. Menerapkan Kode etik dan pedoman perilaku dalam pekerjaan sehari-hari.

4. Bertindak dan mengambil keputusan berdasarkan Kode etik dan Pedoman perilaku yang berlaku di Perusahaan.

5. Melaporkan kemungkinan pelanggaran kode etik dan pedoman perilaku, serta Peraturan Perundang-undangan yang berlaku.

Pedoman Perilaku bagi Manajer Lini dalam mendorong budaya beretika pada PT AJ Adisarana Wanaartha adalah sebagai berikut :

1. Menjadi teladan perilaku yang baik.

2. Menciptakan lingkungan yang mendukung etika perilaku berdasarkan Kode etik dan Pedoman perilaku yang berlaku di Perusahaan.

3. Mendorong Karyawan untuk berperilaku dan mengambil keputusan sesuai dengan Kode Etik dan Pedoman perilaku serta Peraturan Perundang-undangan yang berlaku.

4. Mengantisipasi dan menghentikan kemungkinan terjadinya pelanggaran Kode Etik dan Pedoman serta Peraturan Perundang-undangan yang berlaku. 
Penyusunan Etika Bisnis yang berlaku pada Perusahaan dilandasi dari Integritas Perusahaan yang harus selalu dijunjung tinggi oleh seluruh Karyawan. Integritas dalam PT AJ Adisarana Wanaartha ada dua yaitu :

1. Integritas dalam lingkungan pekerjaan

a. Menjunjung kesetaraan peluang dan kesempatan kerja tanpa memandang latar belakang jenis kelamin, suku. Setiap karyawan bertanggung jawab untuk memegang teguh prinsip tersebut dan menciptakan agama, status pernikahan, dan pandangan politik serta memelihara lingkungan kerja yang positif, serta memastikan bahwa setiap individu diperlakukan dengan adil dan bermartabat.

b. Mencegah Pelecehan

Perusahaan tidak memberikan toleransi terhadap segala bentuk pelecehan,termasuk dan tidaak tertutup pada pelecehan secara fisik dan verbal, seperti perilaku dan/atau ucapan yang mengintimidasi, mengancam, atau merendahkan (misalnya komentar yang bernada rasis atau pelecehan jenis kelamin tertentu).

c. Komunikasi Terbuka

Setiap karyawan wajib memberikan informasi yang akurat dan tepat waktu, yang berkaitan dan dapat membantu pengambilan keputusan bisnis. Dalam hal terdapat perbedaan pendapat, perdebatan yang sehat untuk mengarahkan kepada pengambilan keputusan yang tepat perlu dilakukan.

2. Integritas dalam Bisnis

a. Mendorong dan menghormati praktik bisnis dan persaingan yang adil. Proses bisnis (misalnya pendekatan terhadap calon Nasabah, pemasaran dan penjualan produk, pembayaran claim, negoisasi dan vendor) harus mengedepankan etika bisnis dan integritas, serta dilakukan dengan cara yang adil. Perusahaan tidak memberikan toleransi terhadap manipulasi dan pemberian informasi yang tidak akurat. Proses bisnis juga harus memperhatikan pelaksanaan dari Peraturan Perundang-undangan yang berlaku.

b. Komunikasi Bisnis yang terbuka

Komunikasi dan saluran informasi yang terbuka dan akurat kepada Nasabah dan Mitra Usaha adalah faktor yang harus di penuhi dalam melakukan proses bisnis. Perusahaan dan seluruh Karyawan wajib menyajikan fakta yang akurat mengenai bisnis perusahaan dan tidak boleh menyembunyikan informasi yang dapat merubah keputusan calon Nasabah dan/atau Mitra. Dengan ijin dari bagian komunikasi Perusahaan, informasi harus diberikan dengan cara yang mudah di pahami, akurat dan transparan.

c. Perlindungan atas kerahasiaan

Perusahaan wajib menangani secara hati-hati dan melindungi kerahasiaan informasi pribadi maupun informasi bisnis dari Nasabah, Mitra Kerja, dan Karyawan Perusahaan sendiri. Semua informasi yang diberikan oleh pihak-pihak tersebut kepada Perusahaan tidak boleh diberikan kepada pihak lain, tanpa ijin pemilik informasi.

d. Perdagangan Surat Berharga

Praktik perdagangan surat-surat berharga berdasarkan informasi insider trading, dilarang keras untuk dijalankan. Perdagangan surat-surat berharga hanya boleh 
dilakukan berdasarkan informasi yang sudah diumumkan kepada public. Bila Karyawan bersentuhan dengan informasi yang belum diumumkan kepada public, Karyawan berkewajiban untuk menjaga kerahasiaan informasi tersebut, dan tidak menyalahgunakannya.

e. Anti suap dan Korupsi

Perusahaan menentang keras penggunaan cara-cara yang tidak patut, untuk mempengaruhi peniliaian bisnis dan pengambilan keputusan pihak lain. Semua Karyawan, Manajemen, Direksi, Agen, dan pihak-pihak yang bertindak atas nama Perusahaan dilarang keras menawarkan dan/atau memberikan suap atau keuntungan lain, untuk mendapatkan bisnis atau keuntungan bisnis. Hal tersebut tidak hanya terhadap calon Nasabah dan Mitra Bisnis, namun juga terhadap Pegawai Pemerintahan.

Perusahaan juga memiliki etika dan pedoman perilaku terhadap perlindungan aset, nama baik dan reputasi Perusahaan. Kode etik dan pedoman, serta komitmen integritas, membentuk suatu budaya lingkungan yang memberikan perlindungan kepada Karyawan sebagai individu, dan juga kepada aset, nama baik dan reputasi Perusahaan.

1. Perlindungan terhadap informasi

Informasi sebagai aset perusahaan yang dapat memperengaruhi keputusan bisnis, wajib diperlakukan dengan hati-hati dan seksama.

a. Pencatatan transaksi bisnis dan keuangan wajib dilakukan secara akurat. Pelaporan keuangan harus dilakukan tepatt waktu, secara lengkap dan akurat, untuk mendukung pengambilan keputusan.

b. Penyimpanan catatan dan laporan keuangan dan bisnis, termasuk dan tidak terbatas pada laporan keuangan adalah sesuai ketentuang Perundang-undangan yang berlaku.

c. Penyimpanan informasi yang berkaitan dengan Karyawan, dilakukan dengan hatihati, dengan akses yang terbatas, dengan jangka waktu sesuai peraturan Perundang-undangan yang berlaku.

d. Segala media penyimpanan dan pertukaran informasi harus menggunakan media yang aman.

2. Perlindungan terhadap aset fisik

Merupakan tanggung jawab semua Karyawan untuk melindungi semua aset fisik Perusahaan.

a. Aset fisik Perusahaan dipergunakan untuk kepentingan operasional Perusahaan.

b. Aset fisik harus disimpan di dalam lingkungan Perusahaan, dalam hal aset tersebut dibawa keluar lingkungan Perusahaan, harus dengan Persetujuan petugas berwenang.

c. Setiap perpindahan aset fisik, harus disertai dengan tanda terima.

d. Surat-surat berharga disimpan di lingkungan Perusahaan oleh petugas berwenang.

3. Perlindungan terhadap nama baik dan reputasi Perusahaan

Nama baik dan reputasi Perusahaan adalah aset terpenting yang harus selalu dijaga oleh segenap Karyawan, Manajemen, Direksi, dan Mitra kerja tertentu, seperti misalnya Agent. Salah satu upaya untuk melindungi nama baik dan reputasi Perusahaan adalah dengan menghindari dan/atau meminimalkan terjadinya konflik 
kepentingan. Semua perilaku, tindakan dan keputusan kita tidak boleh melibatkan kepentingan pribadi kita.

Bilamana ada pelanggaran atas perilaku yang bertentangan dengan Etika Bisnis yang berlaku di Perusahaan, maka bagian Kepatuhan (Departemen Compliance) akan menindaklanjuti hal tersebut.

a. Peluang Usaha

Seluruh Karyawan dilarang dilarang mengarahkan pihak ketiga kepada peluang bisnis yang tercipta dari aset, informasi dan posisi Karyawan di Perusahaan. Karyawan dilarang menggunakan aset, property, informasi, dan/atau posisi Karyawan di Perusahaan untuk mendapatkan keuntungan pribadi dalam bentuk apapun. Karyawan dilarang menggunakan aset, property, informasi, dan/atau posisi Karyawan di Perusahaan untuk bersaing dengan PT AJ Adisarana Wanaartha.

b. Pekerjaan aktivitas lain di luar Perusahaan

Karyawan dilarang untuk mempunyai pekerjaan lain di luar PT AJ Adisarana Wanaartha. Segala aktivitas lain di luar pekerjaan dengan Perusahaan harus di informasikan dan dinyatakan kepada Atasan dan HR, untuk menilai potensi terjadinya konflik kepentingan.

c. Hubungan Keluarga

Hubungan dengan anggota keluarga langsung dan orang-orang dekat lainnya tidak menghilangkan kewajiban Karyawan untuk menjalankan Kode Etik dan Pedoman Perilaku Perusahaan dan tidak boleh mempenggaruhi pengambilan keputusan bisnis.

d. Hadiah dan hiburan bisnis

Hadiah dan hiburan bisnis yang Karyawan terima tidak boleh mempengaruhi pengambilan keputusan apapun. Untuk itu, setiap hadiah dan hiburan bisnis yang ditawarkan dan/atau diberikan kepada Karyawan, harus dilaporkan ke Bagian Kepatuhan (Compliance).

Dalam menjalankan Bisnis PT AJ Adisarana Wanaartha juga selalu mengacu pada ketentuan-ketentuan yang berlaku dari Otoritas Jasa Keuangan (OJK) dalam menjual setiap Produk yang di tawarkan Perusahaan kepada calon Nasabah, sehingga Nasabah tidak perlu merasa cemas dalam berasuransi. Peraturan Perusahaan yang berlaku selalu mengacu pada Keputusan Kepala Dinas Tenaga Kerja dan Transmigrasi Provinsi DKI Jakarta nomor 2998 tahun 2018, Peraturan ini juga akan selalu di perbaharui sesuai dengan petunjuk dari Pemerintah Kota. Setiap Karyawan juga akan diberikan Buku pegangan Peraturan Perusahaan setiap ada pembaharuan pada Peraturan yang berlaku. Kepatuhan seluruh Karyawan pada Kode etik dan pedoman perilaku yang berlaku di PT AJ Adisarana Wanaartha akan menghindari timbulnya hal-hal yang dapat merugikan Karyawan, Nasabah, Stakeholder serta Mitra yang memiliki hubungan kerjasama dengan Perusahaan.

\section{KESIMPULAN DAN SARAN}

\section{Kesimpulan}

Dalam menjalankan Bisnis Perusahaan PT AJ Adisarana Wanaartha sudah memiliki Kode Etik dan Pedoman perilaku yang harus selalu dijunjung tinggi oleh Seluruh Karyawan, 
Manajer, dan Direktur. Etika Bisnis yang diterapkan pada PT AJ Adisarana Wanaartha merupakan pedoman dan panduan tertinggi untuk mendorong standar integritas, kepatuhan pada peraturan, dan etika berperilaku di Perusahaan, sebagai perlindungan atas aset, reputasi dan nama baik Perusahaan. Etika Bisnis pada PT AJ Adisarana Wanaartha berlaku sebagai etika dan integritas bisnis perusahaan, yang bukan hanya sekedar pemenuhan Peraturan dan Undang-Undang. Kode etik dan pedoman perilaku mengacu kepada visi, misi dan nilai-nilai perusahaan untuk menjunjung tinggi cerminan nilai-nilai pokok yang disingkat dengan "SATU" yaitu : Service Excellence, Advance, Trust dan Unity.

Penerapan Etika Bisnis merupakan syarat utama Perusahaan agar mampu menjaga nama baik Perusahaan, mampu bersaing dan meminimalisir setiap resiko yang mungkin dihadapi oleh Perusahaan. Dengan semakin ketatnya persaingan di industri Asuransi Jiwa, dimana produk yang dijual relatif sama, maka yang membedakan antara satu perusahaan dengan lainnnya adalah service dan penerapan etika bisnis yang menjadi culture bagi Perusahaan. Dengan adanya buku Peraturan Perusahaan dan Kode Etik dan Pedoman Perilaku diharapkan karyawan bisa selalu patuh dan tunduk akan peraturan yang berlaku. Perusahaan juga memiliki Divisi tertentu yang dapat dihubungi oleh seluruh Karyawan untuk konsultasi mengenai kode etik dan pedoman perilaku kerja yang berlaku di Perusahaan. Kepatuhan seluruh Karyawan pada PT AJ Adisarana Wanaartha akan menghindari timbulnya hal-hal yang dapat merugikan Karyawan, Nasabah, Stakeholder serta Mitra yang memiliki hubungan kerjasama dengan Perusahaan.

\section{Saran}

1. Seluruh Karyawan, Manajer, dan Direktur Perusahaan diharapkan dapat meluangkan waktu untuk membaca, memahami, mengenal dan menerapkan Kode Etik dan Pedoman perilaku dalam aktivitas operasional sehari-hari untuk dapat mendukung tercapainya visi dan misi Perusahaan dan sebai bukti nyata dari nilai-nilai Perusahaan.

2. Perusahaan harus melakukan pengawasan yang ketat serta memberikan sanksi yang tepat bagi seluruh anggota karyawan yang melanggar Kode Etik dan Pedoman Perilaku yang berlaku di Perusahaan.

3. Perusahaan harus selalu konsisten dalam menerapkan nilai-nilai positif dari teori Etika Bisnis (Business Etchics) serta selalu melakukan continuous improvement terhadap perubahan lingkungan eksternal dan internal bisnis yang mempengaruhi kondisi Perusahaan.

\section{DAFTAR RUJUKAN}

Ali, Hapzi. 2020. Modul Perkuliahan Etika Bisnis dan Good Governance Univesitas Mercubuana. Principles of Personal Ethics dan Principles of Professional Ethics. Universitas Mercu Buana.

Andjarwati, A.L., Budiadi, S. 2008. "Etika Bisnis Dan Perilaku Etis Manajer Pengaruhnya Terhadap Tanggung Jawab Perusahaan Pada Lingkungan Sosial”. Jurnal Bisnis dan Manajemen, Vol. I, pp : 1-13.

Echdar, S., Maryadi. (2019). Business Ethics and Enterpreneurship (Etika Bisnis dan Kewirausahaan). Yogyakarta : Deepublish

Fitri Handayani, H. N. (2019). "Pedoman Perilaku Dalam Etika Bisnis di PT. KF". Jurnal Ekonomi Manajemen Sistem Informasi, Vol 1(2), pp: 115-121. 
http://www.wanaarthalife.com/nilaiperusahaan

Rindjin, K. 2008. Etika Bisnis dan Implementasinya. Jakarta : Gramedia

Subagio, T. et al. (2013). Business Crimes and Ethics : Konsep dan Studi Kasus Fraud di Indonesia dan Global., Yogyakarta : ANDI

Yosephus. 2010. Etika Bisnis : Pendekatan Filsafat Moral terhadap Perilaku Pebisnis Kontemporer. Jakarta : Yayasan Pusataka Obor Indonesia. 